Лоскутова А.А., Андреева Е.С.

Донской государственный технический университет (344000 г. Ростов-на-Дону, пл.

Гагарина, дом 1), los6anastasiya@yandex.ru, espmeteo@yandex.ru

Статья посвящена поискам возможностей обеспечения пожарной безопасности на нефтехимических объектах промышленности. Основное внимание в работе авторы уделяют авариям на нефтехимических объектах и причинам их возникновения. Так, аварии на описываемых предприятиях крайне опасны, так как они сопровождаются выбросами в атмосферу различных, в том числе аварийно-химически опасных веществ. Наиболее часто опасность усугубляют сопровождаемые ситуации пожары, взрывы и выбросы опасных веществ. Одними из мер обеспечения пожарной безопасности на предприятиях нефтеперерабатывающей и нефтехимической промышленности являются мероприятия по предупреждению возникновения пожаров или взрывов на исследуемых объектах: исключение возможности образования горючей и взрывоопасной сред, также недопустимость появления в этой среде источников зажигания. Меры по предупреждению таких аварий регламентируются Рекомендациями по обеспечению пожарной безопасности предприятий нефтеперерабатывающей и нефтехимической промышленности, разработанными и утвержденными ФГУ ВНИИПО МЧС России и ГУГПС МЧС России 24.05.2004 г. В связи с тем, что обеспечение безопасности и осуществление мероприятий по недопущению аварий на нефтеперерабатывающих и нефтехимических предприятиях экономичнее, чем устранение значительных последствий аварий, весьма актуальны исследования, ориентированные на поиски современных методов обеспечения пожарной безопасности на предприятиях нефтехимической промышленности.

Ключевые слова: облако газопаровоздушных смесей, химически опасный объект; химическая обстановка, пожарная безопасность.

\title{
THE POSSIBILITY OF ACHIEVING POGANOI SAFETY IN THE PETROCHEMICAL
}

\section{INDUSTRY}

Loskutova A. A., Andreeva E. S.

Don state technical University (344000 Rostov-on-don, Gagarin sq., 1), los6anastasiya@yandex.ru espmeteo@yandex.ru

The article is devoted to find ways to ensure fire safety in petrochemical industry. The focus of the work on the accidents at the petrochemical facilities and their causes. So, the accident on the described enterprises is extremely dangerous, as they are accompanied by emissions of various, including hazardous chemical substances. The most commonly aggravate the risk situations accompanied by fires, explosions and releases of hazardous substances. One of the measures of fire safety at the enterprises of oil refining and petrochemical industry are the prevention of occurrence of fires or explosions on the project: preventing the formation of flammable and explosive environments, also the inadmissibility of occurrence in the environment sources of ignition. Measures to prevent such accidents are governed by the Recommendations for fire safety of the oil refining and petrochemical industry, developed and approved by the FGU VNIIPO of EMERCOM of Russia and gugps MES of Russia 24.05.2004 G. Due to the fact that the security and implementation of measures to prevent accidents in refineries and petrochemical plants more economical than the elimination of the significant consequences of accidents, highly relevant research with a focus on the search of modern methods to ensure fire safety in the petrochemical industry.

Keywords: cloud gazoprovodsk mixtures, chemically dangerous object; chemical environment, fire safety.

Введение.

Как известно, к химически опасным объектам относят такие опасные производственные объекты, на которых хранят, перерабатывают, используют или транспортируют опасные химические вещества. Опасность аварий на подобного рода объектах обусловлена прежде всего гибелью или химическим поражением людей, 
сельскохозяйственных животных и растений, а также химическим заражением окружающей природной среды.

Рассмотрим предприятия нефтехимической промышленности как один и примеров описанных выше химически опасных объектов с точки зрения обеспечения пожарной безопасности на них.

Так, аварии на описываемых предприятиях крайне опасны, так как они сопровождаются выбросами в атмосферу различных, в том числе аварийно-химически опасных веществ. Наиболее часто опасность усугубляют сопровождаемые ситуации пожары, взрывы и выбросы опасных веществ.

В выбросах предприятий нефтехимической отрасли содержатся до 250 химических веществ, треть из которых относятся к I и II классам опасности. При горении нефть и нефтепродукты образуют углекислый газ окись углерода, сернистый газ, азот, полиароматические углеводороды, альдегиды, сажу и другие соединения. Их содержание в продуктах горения тем выше, чем выше плотность нефтепродукта.

Одной из наиболее серьезных опасностей на предприятиях нефтехимической переработки является образование облака газопаровоздушных смесей. Облаком газопаровоздушных смесей обычно считают облако, образованное соединениями углеводородных продуктов (метаном, этиленом, пропаном, парами бензина, и др.) с кислородом воздуха.

На объектах нефтехимической промышленности ежегодно происходят крупные пожары, сопровождаемые значительными социальными и экономическими ущербами. В частности, проведенный анализ аварийно-опасных ситуаций на предприятиях нефтехимической промышленности Российской Федерации показал, что за 2007-2011 гг. произошло 84 опасных события; из них 41 взрыв (49 \% от общего количества опасных событий), 30 пожаров (36 \%) и 13 аварий с выбросом опасных веществ (15\%). Всего за исследуемый период произошёл 51 несчастный случай со смертельным исходом. Поражающими факторами в несчастных случаях со смертельным исходом были ожоги, доля которых составляет 72 \%. Причиной 6 смертельных случаев явилось падение с высоты (12 \%), пониженное содержание кислорода (4\%), поражение взрывной волной (6 \%), поражение при разрушении технических устройств (2 \%), а также прочие (4 \%) [1].

Указанные выше обстоятельства во многом актуализируют тему данного исследования.

Основными источниками пожаров на нефтехимических объектах являются: утечки горючей жидкости или углеводородного газа, нарушение правил техники безопасности и пожарной безопасности, некачественный монтаж и ремонт оборудования; некачественная 
молниезащита; нарушение правил технологического регламента; износ оборудования; недостаточно качественные сальниковые уплотнения и фланцевые соединения; нарушение режима работы оборудования, неисправность электрооборудования, самовозгорание материалов.

Одними из мер обеспечения пожарной безопасности на предприятиях нефтеперерабатывающей и нефтехимической промышленности являются мероприятия по предупреждению возникновения пожаров или взрывов на исследуемых объектах: исключение возможности образования горючей и взрывоопасной сред, также недопустимость появления в этой среде источников зажигания. Меры по предупреждению таких аварий регламентируются Рекомендациями по обеспечению пожарной безопасности предприятий нефтеперерабатывающей и нефтехимической промышленности, разработанными и утвержденными ФГУ ВНИИПО МЧС России и ГУГПС МЧС России 24.05.2004 г. [2]

Данный документ содержит требования пожарной безопасности для предприятий нефтеперерабатывающей и нефтехимической промышленности и их опасных производственных объектов, которые должны быть учтены при проектировании, строительстве, расширении, реконструкции или техническом перевооружении указанных предприятий. Так, до ввода предприятия в эксплуатацию должны быть разработаны мероприятия по обеспечению пожарной безопасности при его пуске и возможной остановке. Очевидно, что эффективность мероприятий, указанных в настоящем документе, должна быть обоснована на этапе проектирования.

Мониторинг химически опасных объектов при постоянном контроле используемых аварийно химически опасных веществ также относится к еще одним мерам обеспечения пожарной безопасности. Так, на предприятиях нефтеперерабатывающей промышленности, непосредственно связанной с химическими процессами, немало важно производить оценку химически опасных объектов с установленной периодичностью в соответствии с ГОСТ 12.1.005, ГОСТ 17.2.4.02, ГОСТ Р 8.589 [3]. При проведении проверки к химически опасным объектам предъявляют особые требования, которые включают в себя наблюдение и контроль за параметрами предприятия. К таким параметрам относятся: состояние систем, которые определяют безопасную работу с аварийными химически опасными веществами; возможные пути попадания аварийно химически опасных веществ в атмосферу, гидросферу и литосферу с территории химически опасных объектов; своевременное и качественное проведения ремонтных работ с резервуарами, в которых находятся аварийно химически опасные вещества; сообщения о состоянии окружающей природной среды и об аномальных явлениях в районе расположения химически опасных объектов; контроль за состоянием 
систем уведомления об аварии на химически опасных объектах и угрозе поражения населения; подготовленность личного состава, органов управления и подразделений МЧС России к действиям в случае аварии на химически опасных объектах и другие [4].

Так же для предупреждения возникновения аварий на химически опасных объектах можно воспользоваться методикой прогнозирования масштабов заражения сильнодействующими ядовитыми веществами при авариях на химически опасных объектах и транспорте. Методика предназначена для заблаговременного и эффективного прогнозирования диапазонов заражения при попадании сильнодействующих ядовитых веществ в окружающую среду. Данная методика распространяется на случай выбросов сильнодействующих ядовитых веществ в атмосферу в газообразном, парообразном или аэрозольном состоянии [5].

При выборе средств и способов пожаротушения важно обеспечивать условия наиболее эффективной пожарной защиты при наименьших затратах.

В случае технологических процессов, размещаемых в зданиях, одним из наилучших способов является объемное тушение с применением газовых составов. Такой способ пожарной защиты обеспечивает не только пожаротушение, но и предупреждение образования взрывоопасной среды и дает возможность потушить пожар независимо от его масштабов за очень короткое время (30 с и даже менее в зависимости от конкретных условий) [6]. Эффективность и надежность способа существенно возрастают при использовании составов на основе галоидоуглеводородов и, в частности, комбинированных газовых составов (типа «хладон-азот» или «хладон-двуокись углерода»). Весьма эффективны составы на основе хладона 13В1, так как они практически безвредны и могут в отдельных случаях использоваться в присутствие людей [7].

Газовые галоидоуглеводородные составы целесообразно использовать в тех случаях, когда защищаемое здание в начальный момент пожара сохраняет некоторую герметичность, обеспечивая тем самым возможность накопления в атмосфере огнетушащих агентов до нужной концентрации [8].

Для объектов нефтехимической промышленности, в которых обращаются большие количества легковоспламеняемых жидкостей и в которых нельзя осуществить объемное тушение (здания с очень большой площадью застекления, открытые установки), следует предусматривать стационарные пенные или порошковые установки. К достоинствам первых относятся высокая надежность тушения (особенно с помощью средне- и высокократной пен), сравнительная простота устройств и другое. К недостаткам пенной системы относятся необходимость создания специального хозяйства и надзора за ним: насосной, хранилища раствора пенообразователя, сложной системы трубопроводов, дренажа в местах защиты [9], а 
также опасность замерзаний и сравнительно большое время тушения. Крупные пенные системы являются довольно дорогостоящими сооружениями.

В заключении следует отметить, что организационная деятельность в области прогнозирования и мониторинга чрезвычайных ситуаций на нефтеперерабатывающих и нефтехимических предприятиях требует осуществления контроля химической обстановки как на самом предприятии, так и на прилежащей к ней территории. А, в связи с тем, что обеспечение безопасности и осуществление мероприятий по недопущению аварий на нефтеперерабатывающих и нефтехимических предприятиях экономичнее, чем устранение значительных последствий аварий, весьма актуальны исследования, ориентированные на поиски современных методов обеспечения пожарной безопасности на предприятиях нефтехимической промышленности.

\section{Список литературы}

1. Адамян В.Л. Обеспечение пожарной безопасности на предприятиях строительства//Инновации и инвестиции,№10, 2015, с. 114 - 116.

2. Безопасность в чрезвычайных ситуациях. Мониторинг химически опасных объектов. Общие требования. ГОСТ Р 22.1.10-2002/ Утвержден Постановлением Госстандарта РФ от 25.10.2002 N 394-ст.

3. Евстропов В.М. Опасные природные и производственные процессы. Медицина катастроф: Министерство образования и науки Российской Федерации, Федеральное агентство по образованию, Федеральное гос. образовательное учреждение высш. проф. образования "Ростовский гос. строит. ун-т". Ростов-на-Дону, 2005.

4. Ефремян Д.А., Плаксина И.В., Сергеева Г.А. Обеспечение пожарной безопасности высотных зданий в России//Аллея науки, Т.3,№9, 2017, с. 754 - 760.

5. Корецкая М.С., Андреева Е.С. Актуальность обеспечения пожарной безопасности в зданиях повышенной этажности и анализ нормативной литературы/ Инновации и инжиниринг в формировании инвестиционной привлекательности региона: Сборник научных трудов II Открытого международного научно-практического форума. Ростов-на-Дону: Изд-во ДГТУ-Принт, 2017, с.28 - 33.

6. Лебедева М.И., Богданов А.В., Колесников Ю.Ю. Аналитический обзор статистики по опасным событиям на объектах нефтеперерабатывающей и нефтехимической промышленности//Технологии техносферной безопасности №4(50), 2013, 9 с.

7. Меднов А.О., Попова Е.С. Обеспечение пожарной безопасности на основе изучения особенностей развития пожаров и учета применяемых легковоспламеняющихся 
жидкостей// Труды Ростовского государственного университета путей сообщения/ Научно-технический журнал, №3 (40), 2017 г., г. Ростов-на-Дону, с.82 - 84.

8. Рекомендации обеспечению пожарной безопасности предприятий нефтеперерабатывающей и нефтехимической промышленности/Утверждены ФГУ ВНИИПО МЧС России и ГУГПС МЧС России 24.05.2004 г.

9. Тишкова И.М., Андреева Е.С. Обеспечение пожарной безопасности в портах Ростовской области/ Труды международной конференции «Природопользование и охрана окружающей среды», «Nature management and environmental protection», Нидерланды (Амстердам), 20 - 27 октября 2017 года//Журнал экспериментального образования,№8, 2017, с. 34 . 